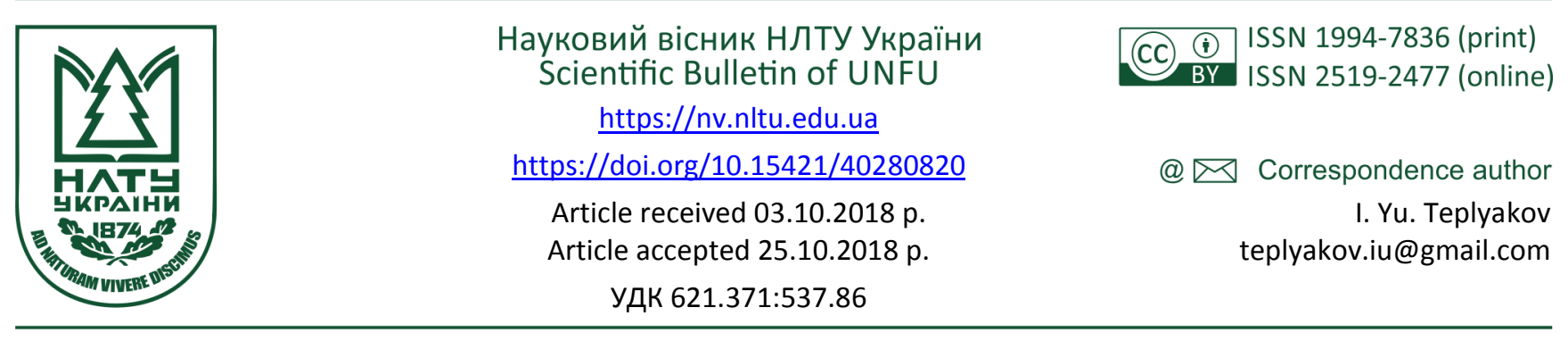

І. Ю. Тепляков, О. М. Ліске, І. В. Гадьо, С. О. Маслаков

Національний університет "Львівська політехніка", м. Львів, Украйна

\title{
ДОСВІД РОЗРОБЛЕННЯ ТА ВИКОРИСТАННЯ ЗАСОБІВ ІНФОРМАЦІЙНИХ ТЕХНОЛОГІЙ НА ПІДСТАВІ МЕТАЛ-ДІЕЛЕКТРИЧНИХ СТРУКТУР ТА ПЛАЗМОВОГО РОЗРЯДУ
}

Наведено результати аналізу принципів побудови та прикладів застосування сучасних засобів інформаційних технологій на базі метал-діелектричних структур. Виявлено, що стрімкий розвиток сучасних засобів інформаційних технологій зумовлений використанням фізичних властивостей поверхневих плазмонів і поверхневих плазмон-поляритонів. Оцінено вплив модуляції поверхневого імпедансу метал-діелектричних структур на форму просторового розподілу поля. Виявлено, що в засобах передавання електромагнітної енергії ефективно використовується гофрована металева структура в ролі штучного діелектрика для сповільнення рухомої поверхневої хвилі. З'ясовано, що технологія збудження поверхневих плазмонів за геометрією Кретчмана дотепер широко вживана в засобах інфокомунікацій. Встановлено, що вагому роль у розвитку сучасних випромінювальних засобів інформаційних технологій відіграє використання високоіонізованого газу як компонента структури, здатної поширювати поверхневі плазмон-поляритони. Виявлено низку переваг засобів інформаційних технологій на базі плазмового розряду, які зумовлені фізичними особливостями плазми. Досліджено сучасні інформаційно-комп'ютерні технології модельних досліджень електродинамічних параметрів випромінювальних засобів. на підстаі здійсненого аналізу запропоновано використання ребристо-стержневих структур на базі плазмового розряду в ролі засобів передавання електромагнітної енергії.

Ключові слова: поверхневий плазмон-поляритон; метал-діелектрична структура; плазма.

Вступ. Інтенсивний розвиток сучасних інформаційних технологій супроводжується великою кількістю теоретичних та експериментальних досліджень металдіелектричних структур (МДС), в яких стороннім джерелом поля на межі металу та діелектрика збуджуються поверхневі електромагнітні хвилі (ПЕХ). Вагомий внесок у розвиток теорії та математичного апарату структур на підстаі ПЕХ належить вітчизняним та зарубіжним вченим: Г. Т. Маркову, А. Ф. Чапліну, Д. М. Сазонову, А. Л. Драбкіну, В. В. Гоблику, І. М. Болесті, Ф. Ф. Дубровці, В. В. Овсянікову, А. А. Пістолькорсу, А. Отто, Е. Кретчманну та ін. Для забезпечення можливості передачі великих обсягів інформації виникає потреба у використанні гігагерцового та терагерцевого діапазону. Це досягається завдяки використанню поверхневих плазмонів (ПП) та поверхневих плазмон-поляритонів (ППП), які, водночас, є окремими випадками ПЕХ. Актуальність досліджень у сфері плазмоніки зумовлена тим, що завдяки ПП можна концентрувати електромагнітну енергію в малих відносно довжини хвилі світла об'ємах. Електродинамічні прилади на базі ПП та ППП характеризуються високою надійністю та точністю роботи, низькими енергетичними та економічними затратами, малими геометричними розмірами та простотою виготовлення конструкції.

Останнім часом значно підвищився інтересу до задачі дослідження просторового розподілу поля випромінювання засобів на базі плазмового розряду, яка є актуальною, оскільки має важливе практичне значення для вдосконалення наявних та створення нових компонентів інфокомунікацій, основаних на стандарті WiGig, а також для потреб військового призначення, наприклад, для розроблення нових та покращення ефективності наявних засобів прихованої радіолокації.

Антени на базі рухомих поверхневих електромагнітних хвиль. Серед інфокомунікаційних пристроїв, побудованих на підстаі МДС, особливе місце займають антени поверхневої хвилі (АПХ), які призначені для пе-

Інформація про авторів:

Тепляков Іван Юрійович, аспірант, кафедра електронних засобів інформаційно-комп'ютерних технологій. Email: teplyakov.iu@gmail.com; https://orcid.org/0000-0001-5178-5977

ліске Олексій Миколайович, ст. викладач, кафедра електронних засобів інформаційно-комп'ютерних технологій. Email: teplyakov.iu@gmail.com; https://orcid.org/0000-0001-6298-1893

Гадьо Ірина Володимирівна, канд. техн. наук, доцент, кафедра електронних засобів інформаційно-комп'ютерних технологій. Email: teplyakov.iu@gmail.com; https://orcid.org/0000-0003-1615-6483

Маслаков Сергій Олександрович, аспірант, кафедра електронних засобів інформаційно-комп'ютерних технологій. Email: teplyakov.iu@gmail.com

Цитування за ДСтУ: Тепляков І. Ю., Ліске О. М., Гадьо І. В., Маслаков С. О. Досвід розроблення та використання засобів інформаційних технологій на підставі метал-діелектричних структур та плазмового розряду. Науковий вісник НлтУ України. 2018, т. 28, № 8. С. 95-100.

Citation APA: Teplyakov, I. Yu., Liske, O. M., Gado, I. V., \& Maslakov, S. O. (2018). The experience of development and use of information technology tools based on metal-dielectric structures and plasma discharge. Overview. Scientific Bulletin of UNFU, 28(8), 95-100. https://doi.org/10.15421/40280820 
редавання та приймання радіосигналів дециметрового, сантиметрового та міліметрового діапазону хвиль. АПХ у діапазоні НВЧ становлять широкий клас випромінювальних електродинамічних пристроїв, які умовно можна розділити за такими критеріями: за формою поверхні, за методом живлення та за типом конструкції. За типом конструкції АПХ поділяють на діелектричні (виготовлені $з$ природного діелектрика), ребристі (виготовлені зі штучного діелектрика), метал-діелектричні та АПХ побудовані на підстаі плазми, а за формою поверхні відомі такі види: плоскі (імпедансні), стержневі, Уда-Яги, спіральні та дискові, які, водночас, бувають коловими або еліптичними (Milligan, 2005; Markov, \& Sazonov, 1975; Krasiuk, 1986; Drabkin, Zuzenko, \& Kislov, 1974; Hoblyk et al., 2016).

В АПХ замість діелектрика із гладкою поверхнею часто використовують періодичну структуру у вигляді гофрованої металевої поверхні, у якій глибина канавки зазвичай становить $0.1 \lambda$. Таку гофровану структуру можна розглядати як шар штучного діелектрика, в якому відбувається сповільнення швидкості ПЕХ. Такий процес сповільнення ПЕХ у канавках пояснюється збільшенням віддалі проходження поверхневого струму внаслідок його проникнення у канавки.

Концентрація основної потужності, що переноситься ПЕХ, локалізована поблизу поверхні АПХ (Drabkin, Zuzenko, \& Kislov, 1974). У разі зміні робочої частоти зазвичай спостерігається різка зміна фазової швидкості у сповільнювальній системі, а також ефективність та якість узгодження збуджувальної системи (Markov, \& Sazonov, 1975).

Часто в АПХ використовують сповільнювальні імпедансні поверхні (Andreas, 1968) за потреби синтезу об'єктів зі заданими розсіювальними властивостями, а також під час дослідження проблем, які виникають при розв'язці розташованих на спільних поверхнях антен, для зменшення взаємного впливу між передаючою та приймаючою антенами. Розв'язуючими засобами в таких випадках зазвичай виступають металеві поверхні, в яких вирізані металеві канавки (Kiurkchan, 1985).

За малих розмірів поперечного перерізу випромінювальної системи проявляється унікальність АПХ, яка полягає у високому значенні коефіцієнта спрямованої дії, що є особливо важливим для антен зворотного випромінювання (Aizenberg et al., 1985).

Значний прорив у дослідженні процесу трансформації рухомої поверхневої хвилі в об'ємну та особливостей формування просторового розподілу поля імпедансних антен належить Г. Т. Маркову, А. Ф. Чапліну та В. В. Гоблику. Вони розробили теорію, яка грунтується на аналітичних виведеннях, що адекватно описує антени на базі ПЕХ.

Дискові діелектричні антени. Такі антени збуджуються за допомогою чверть хвилевого вертикального вібратора, який розташований в центрі диска у вигляді діелектричної підкладки на металевому екрані. Дискові діелектричні антени використовують для формування відносно вузьких діаграм спрямованості, ширина головних пелюстків яких знаходиться в межах від 15 до $25^{\circ}$. Особливим випадком дискових діелектричних антен стало покриття діелектрика металевою смужкою у вигляді спіралі Архімеда. Така система збуджується радіальною поверхневою хвилею, яка поширюється від центра диску. На базі цієї дискової метал-діелектричної структури розроблено серію коліматорів зі спіральними неоднорідностями (Hoblyk, \& Subota, 2011).

Iмпедансні антени. Такі антени складаються 3 модульованого діелектричного покриття, нанесеного на металевий екран або з металевої пластини, гофрованої за періодичним законом канавками. Живлення імпедансних антен досягається за допомогою прямокутного рупора, на вхід якого від генератора подається електромагнітна хвиля. В деяких випадках можлива заміна рупора системою прорізаних в екрані щілинних випромінювачів. Поверхнева хвиля поширюється уздовж ребристої структури майже без зміни амплітуди, що пояснюється малим значенням відбиття хвилі від кінця структури.

Теорія та аналітичний розрахунок просторового розподілу поля антени на базі поверхневої хвилі, поверхневий імпеданс якої модульований прямокутними імпульсами, отримано в (Hoblyk, 1986). Розвиток цього напрямку продовжено у роботах (Hoblyk, 2012, 2015), в яких розроблено теорію та математичні моделі плоских МДС, поверхневий імпеданс яких модульований трикутними функціями. При цьому наведено порівняння просторових розподілів поля МДС, в яких трикутними та прямокутними функціями модульовано поверхневий імпеданс. Приклад розв'язку задачі знаходження поверхневого розподілу струму на імпедансній поверхні наведено в роботі (Markov, \& Chaplin, 1967).

Стержневі антени поверхневої хвилі. Поряд з плоскими імпедансними антенами використовують стержневі антени, в яких поширення рухомих поверхневих хвиль відбувається уздовж прямолінійного стержня (Milligan, 2005). За геометричною конфігурацією стержня виділяють такі різновиди антен: конічноподібні, циліндричні та ребристо-стержневі. У перших двох випадках стержень може бути як суцільним, так і порожнім (Drabkin, Zuzenko, \& Kislov, 1974). Унікальність ребристо-стержневої антени (РСА) зумовлена тим, що в роді імпедансної сповільнювальної структури використано систему металевих дисків (кілець), які насаджені або прорізані уздовж центрального стержня (Lobkova, 2002). Живлення цієї антени забезпечується за допомогою дротового вібратора або рупора.

Максимум випромінювання РСА спрямований уздовж осі антени. Відомо, що за направленими властивостями РСА близькі до антен Уда-Яги, тоді систему дисків можна трактувати у вигляді плоских вібраторів (Milligan, 2005). Такі характеристики дають змогу використовувати РСА на поверхні літальних космічних апаратів, яким потрібно забезпечити направлений радіозв'язок з Землею.

У роботі (Hoblyk \& Pavlysh, 2009) продовжено вивчення циліндричних метал-діелектричних структур, поверхневий імпеданс яких змінюється за періодичним законом. Роботі розроблено математичні моделі, які належать до класу гіллястих ланцюгових дробів, на базі яких розраховано просторові розподіли поля. Виявлено, що зміна параметрів циліндричної метал-діелектричної структури призводить до зміни форми розподілу просторового поля. Саме цей факт дає змогу використовувати такі структури як базові для розроблення широкого класу радіотехнічних пристроїв та засобів інфокомунікацій.

Варіювання напряму випромінювання РСА в широких межах досягається за допомогою зміни параметрів 
структури РСА, а саме: періоду та довжини металевих радіальних неоднорідностей, які математично мають зміст прямокутних імпульсних функцій у математичній моделі (Hoblyk \& Pavlysh, 2009), а також глибини модуляції. Відомо (Goblik, 1984), що подібний ефект також можна досягти через зміну електричних параметрів антени (діелектричної проникності тощо).

Огляд сучасних приладів, основаних на використанні явища поверхневого плазмонного резонансу та поверхневих плазмон-поляритонів. Можливості використання ПП та ППП у приладах інтегральної оптики зумовлюють ріст інтересу до створення приладів на базі цього явища, при цьому за останні роки ППП досліджуються у терагерцовому діапазоні частот.

Мікроскоп на базі поверхневих плазмонів. У 1987 р. вийшла перша доповідь про мікроскоп на базі ПП, який використовував розширений колімований промінь у конфігурації Кретчмана. Згодом було опубліковано схожі результати досліджень, відмінність яких полягала у конструкції мікроскопа, який використовував скануючий промінь (Yeatman, 1996).

Принцип роботи мікроскопа на базі ПП описано в роботах (Valianskii, 1999; RothenhKusler, \& Knoll, 1988). Основна особливість роботи цього мікроскопа полягає в тому, що він реагує на добуток діелектричної проникності та товщини вимірюваного об'єкта. Роздільна здатність залежить від відстані, на яку розповсюджується ПП, що, водночас, залежатиме від рівності поверхні металевої плівки та від уявної частини діелектричної проникності матеріалу плівки. Встановлено, що найкращим у цьому сенсі матеріалом $є$ срібло (довжина шляху розповсюдження плазмонів сягає 100 мкм).

Біосенсорні системи на базі поверхневого плазмонного резонансу. Технологія розроблення біосенсорів на базі поверхневого плазмонного резонансу (ППР) на цей час $€$ найсучаснішою технологією створення біосенсорів, оскільки вона $є$ найбільш доступною та практично вживаною для потреб біохімічного аналізу крові на глюкозу, сечовину, аналізів гормонів, білків, стероїдів вірусів, аналізу ДНК, ліків, а також для дослідження кінетики дії ліків в реальному масштабі часу (Dorozhynskyi, Maslov, \& Ushenin, 2016; Shpacovitch, 2012). Усі біосенсори на базі ППР використовують властивості сильної локалізації ПП поблизу поверхні розділу контактуючих середовищ та високої чутливості до зміни діелектричних властивостей поверхні. Основний метод збудження ПП у біосенсорах на базі ППР стала оптична конфігурація, яка отримала назву Кретчмана (у деякій літературі іiї називають геометрією Кретчмана) (Dorozinsky, 2013).

Спектрометр "PLASMON-6" на базі поверхневого плазмонного резонансу. В інституті фізики напівпровідників ім. В. С. Лашкарьова НАН України впродовж багатьох років проводять експериментальні дослідження для потреби у виготовленні біосенсорів на базі ППР (Khristosenko et al., 2011). У цій роботі розроблено модель спектрометра "PLASMON-6", яка успішно зарекомендувала себе під час експериментальних досліджень в лабораторіях біохімічного та біофізичного профілів.

Спектрометр "PLASMON-6" за своєю суттю є керованим комп'ютером, вимірювальна частина якого реалізована у конфігурації Кретчмана, при цьому прилад здатний вимірювати зразок досліджуваної речовини в автоматизованому режимі. Пристрій дає змогу працю- вати 3 аналітиками, показник заломлення яких знаходиться в діапазоні 1.33 1.7. Введення паралельного додаткового контрольного каналу є основною особливістю спектрометра "PLASMON-6" (Hoblyk, 1986; Valianskii, 1999; RothenhKusler, \& Knoll, 1988).

Інтерферометри на базі поверхневого плазмонного резонансу. У літературі (Dorozhynskyi, Maslov, \& Ushenin, 2016) відомі конструкції інтерферометрів на базі ППР, призначених для визначення фазового зсуву ПЕХ шляхом аналізу інтерференційної картини. Прототипом таких конструкцій став інтерферометр Маха-Цендера. Зазначимо, що існують модифікації сенсорів на базі ППР, робота яких основана на методах інтерферометрії. Для цього в ролі прототипів використовують інтерферометри Майкельсона (Shpacovitch, 2012) та Фабрі-Пеpo (Dorozinsky, 2013). Принцип роботи інтерферометра на базі ППР полягає у вимірюванні зсуву фази відбитого променя світла.

Гетеродинний інтерферометр на базі поверхневих електромагнітних хвиль. Гетеродинний інтерферометр на базі ПЕХ було винайдено та результативно апробовано для потреб вимірювання фазової швидкості ПЕХ (Khristosenko et al., 2011). Основними конструктивними елементами $\epsilon$ лазер та дифракційні гратки введення та виведення ПЕХ. Принцип роботи гетеродинного інтерферометра на базі ПЕХ полягає у використанні явища інтерференції, при цьому спостерігаються низькочастотні биття на різній частоті.

Спазер на базі поверхневих плазмонів. Можливість генерування та підсилення плазмових хвиль у нанопристроях, в середині яких створюється сильне когерентне поле у просторовій області, що $є$ набагато меншою за довжину хвилі, розглянуто в роботі (David et al., 2003). Подальший розвиток цього напряму наведено в роботі (Zheludev et al., 2008), в якій показано можливості створення спазера на підстаі комбінації фотонного метаматеріалу та когерентного джерела вузько направленого електромагнітного випромінювання.

Довгий час вважали, що джерело когерентного випромінювання повинно мати розміри не менші, ніж половина від згенерованої ним довжини електромагнітної хвилі - умова резонансу в оптичній системі. Використання плазмового резонатору дало змогу подолати цей бар'єр та відкрило шлях новим технологіям (Stockman, 2011).

Сучасні засоби передавання електромагнітної енергії на базі плазмового розряду. На початку XX ст. було запропоновано використання плазми для передавання та приймання радіосигналів. Відтоді відбувається значне підвищення інтересу до задач дослідження просторового розподілу електромагнітного поля випромінювальних засобів, які розроблені на базі плазмового розряду. В загальному випадку такими засобами є плазмові антени (ПА), які складається зі скляної трубки, заповненої інертним газом або парами ртуті (Jenn, 2003; Bogachev, Bogdankevich, \& Gusein-zade, 2014; Kyrychenko, Karlov \& Kiiko, 2017; Sergeichev \& Minaev, 2014).

Використання неіонізованого газу в ПА призводить до зменшення розсіювання нею електромагнітного поля, при цьому зменшується вплив наведених нею завад на інші близько розташовані антени. Такий "вимкнений стан роботи" робить ПА невидимою для радарів та інших засобів РЕБ (Patel, Masani, \& Parekh, 2014). Також для ПА характерний набагато менший тепловий шум, 
на відміну від звичайних металевих антен. У роботі (Bogachev, Bogdankevich \& Gusein-zade, 2014) досліджено вплив насиченості плазми на форму діаграми спрямованості ПА. Основні недоліки ПА зумовлені високою вартістю та складністю виготовлення конструкції антени (Shriwas \& Gulhane, 2015).

Визначено (Vecchioni et al., 2016) вплив довжини газорозрядної трубки (відстань між електродами) та оптимальну провідність плазми на ефективність роботи ПА. $\mathrm{y}$ роботах (Bogachev, Bogdankevich, \& Gusein-zade, 2014; Patel, Masani, \& Parekh, 2014; Kumar, \& Kumar, 2016) наведено результати дослідження просторового розподілу поля ПА, які було отримано в програмному коді КАРАТ та в засобах автоматизованого проектування EMpro та Ansoft HFSS. У роботі (Shriwas, \& Gulhane, 2015) обчислено втрати потужності сигналу та наведено схему випромінювального засобу на базі 12 газорозрядних ламп, які в експериментальному макеті заповнені ртуттю та аргоном.

Отже, результати чисельного моделювання та експериментального дослідження ПА, в яких поширення поверхневих рухомих хвиль відбувається в гладкій діелектричній трубці, заповненої парами ртуті, добре відомі. Результати досліджень випромінювальних засобів на базі плазмового розряду зі складним профілем поверхневого імпедансу ще недостатньо вивчені. У роботах (Shchadylo et al., 2018a, 2018b) проведено теоретичне та експериментальне дослідження можливостей та особливостей використання плазмового розряду під час виготовлення РСА. Використання високоіонізованого газу в ролі компонента структури РСА дало змогу отримати випромінювальний засіб, який може бути електрично невидимий за відсутності плазми.

Висновки. У роботі розглянуто особливості побудови сучасних пристроїв, побудованих на базі поверхневих електромагнітних хвиль. Це дало змогу зрозуміти суть конструктивних особливостей таких електродинамічних засобів, як антени, інтерферометри, мікроскопи, біосенсори, спазери та оглянуто сфері застосування цих пристроїв. З'ясовано основні принципи формування ними просторового електромагнітного поля.

Виявлено, що період та довжина металевих радіальних неоднорідностей, а також глибина модуляції в конструкціях антен поверхневих хвиль дають змогу змінювати форму просторового розподілу поля в дальній зоні. Цей ефект можна використати під час розроблення нових засобів, таких як антени та інтерферометри, 3 необхідними електродинамічними характеристиками.

Встановлено низку переваг структур на базі плазмового розряду порівняно з традиційними металевими, які зумовлені фізичними особливостями плазми. Огляд методів моделювання випромінювачів на базі плазмового розряду виявив, що під час дослідження таких засобів широко використовують скінченно-різницевий метод у часовій області, а також метод скінчених елементів. на підстаі проведеного аналізу виявлено, що перспективним напрямком $\epsilon$ розроблення та дослідження нових випромінювачів на базі плазмового розряду. Для цього за основу можна взяти стержневі антени поверхневої хвилі, в яких центральний стержень буде замінений плазмою. Схожість конструкції плазмових і ребристостержневих антен дає підстави припустити, що ті самі параметри будуть аналогічно впливати на форму просторового розподілу поля.

\section{Перелік використаних джерел}

Aizenberg, A. Z. (Ed.), Belousov, S. P., Zhurebnko, E. M., et al. (1985). Korotkovolnovye antenny, (2nd ed.). Moscow: Radio i sviaz, 536 p. [In Russian].

Andreas, O. (1968). Exitation of nonradiative surface plasma waves in silver by the method of frustrated total reflection. A. Z. Physik, 216, 398-410.

Bogachev, N. N., Bogdankevich, I. L., \& Gusein-zade, N. G. (2014). Modelirovanie rezhimov raboty plazmennoi antenny. Prikladnaia fizika, 4, 39-45. [In Russian].

David, J., Stockman, I. Bergman, \& Stockman, I. Mark. (2003). Surface Plasmon Amplification by Stimulated Emission of Radiation: Quantum Generation of Coherent Surface Plasmons in Nanosystems. Physical Review Letters, 90(2), 53-59.

Dorozhynskyi, H. V., Maslov, V. P., \& Ushenin, Yu. V. (2016). Sensorni prylady na osnovi poverkhnevoho plazmonnoho rezonansu: monohrafiia. Kyiv: NTUU "KPI", 264 p. [In Ukrainian].

Dorozinsky, G. (2013). Surface plasmon resonance as a tool for research in nanotechnology and industry. Machines, technologies, materials, 9, 51-54.

Drabkin, A. L., Zuzenko, V. N., \& Kislov, A. G. (1974). Antenno-fidernye ustroistva, (2nd ed.). Moscow: Sovetskoe radio. [In Russian].

Goblik, V. V. (1984). Analiz polia nad impedansnoi ploskostiu s periodicheskimi diskretnymi neodnorodnostiami metodom A. F. Chaplina. Teoreticheskie i eksperimentalnye metody issledovaniia antenn i ustroistv SVCh: Sbornik trudov, (pp. 27-70), m. Lvov. Politekhn. in-t. Lvov, Rus. Dep. v UkrNIINTI 11.11.84, № 1874, Uk, 84. [In Russian].

Hoblyk, V. (2015). Mathematical model antennas, based on modulated plazmon - polariton structures. Plasma Electronics and New Acceleration Methods: Program XIIIth International Conference, (PENAM-2015), (pp. 12-18), August, 24-28, Kharkiv, Ukraine, $312 \mathrm{p}$.

Hoblyk, V. V. (1986). Analyz polia nad ympedansnoi ploskostiu s peryodycheskymy dyskretnymy neodnorodnostiamy metodom A. F. Chaplyna. Doctoral Dissertation for Physics and Mathematics Sciences (01.04.14 - Thermophysics and molecular physics), Kharkivskyi derzhuniversytet, $210 \mathrm{p}$. [In Ukrainian].

Hoblyk, V. V. (2012). Elektromahnitne zbudzhennia impedansnykh struktur z N-kratnoiu periodychnistiu. Visnyk Natsionalnoho universytetu "Lvivska politekhnika". Seriia: Elektronika, 734, 134-144. [In Ukrainian].

Hoblyk, V. V., \& Pavlysh, V. A. (2009). Matematychni modeli periodychno-neodnoridnoho dielektrychnoho tsylindra ta yikh analiz. Visnyk Natsionalnoho universytetu "Lvivska politekhnika". Seriia: Radioelektronika ta telekomunikatsii, 645, 197-204. [In Ukrainian].

Hoblyk, V. V., \& Subota, I. B. (2011). Doslidzhennia polia kolimatora na osnovi plazmonnoho krystalu. Chotyrnadtsiata vidkryta naukovo-tekhnichna konferentsiia Instytutu telekomunikatsii, radioelektroniky ta elektronnoi tekhniky Natsionalnoho universytetu "Lvivska politekhnika" z problem elektroniky: tezy dopovidei, (pp. 23-29) 5-7 kvitnia 2011 r., m. Lviv. Lviv: Vydavnytstvo Lvivskoi politekhniky, 21 p. [In Ukrainian].

Hoblyk, V. V., Liske, O. M., Nychai, I. V., \& Tepliakov, I. Yu. (2016). Modeliuvannia protsesiv elektromahnitnoho vidklyku v modulovanykh nanorozmirnykh metal-dielektrychnykh ta napivprovidnykovykh strukturakh. Rozdil 1. DB TEZA, № derzhreiestratsii 0113U001354, vykonanu u Natsionalnomu universyteti "Lvivska politekhnika", m. Lviv, (pp. 10-45). [In Ukrainian].

Jenn, D. C. (2003). Plasma antennas: Survey of Techniques and the Current State of the Art. Naval Postgraduate School, Prepared for SPAWAR PMW 189, San Diego, $27 \mathrm{p}$.

Khristosenko, R. V., Nesterova, N. V., Kostiukevich, E. V., Zagorodniaia, S. D., Baranova, G. V., Golovan, A. V., Ushenin, Iu. V., Samoilov, A. V., \& Kostiukevich, S. A. (2011). Immunosersor na osnove poverkhnostnogo plazmonnogo rezonansa dlia opredeleniia 
antitel protiv virusa Epshteina-Barr. Optoelektronika i poluprovodnikovaia tekhnika, 46, 32-38. [In Russian].

Kiurkchan, A. G. (1985). Sviaz mezhdu antennami v prisutstvii rebristykh struktur. Radiotekhnika i elektronika, 22(7), 1362-1365. [In Russian].

Krasiuk, V. N. (1986). Antenny s dielektricheskim pokrytiiami (osobennosty rascheta i proektirovaniia). Leningrad: Sudostroenie, 164 p. [In Russian].

Kumar, Prince, \& Kumar, Rajneesh. (2016). Simulation of Plasma Antenna Parameters. International Journal of Engineering Technology, Management and Applied Sciences, 4(5), 63-69.

Kyrychenko, Yu. V., Karlov, V. D., \& Kiiko, A. S. (2017). Osoblyvosti vykorystannia ploskoho sharu plazmy z malym vyhynom v antennykh systemakh. Zbirnyk naukovykh prats Kharkivskoho natsionalnoho universytetu Povitrianykh Syl, 4(53), 42 49. [In Ukrainian].

Lobkova, L. M. (2002). Proektirovanie antenn i ustroistv SVCh: uchebnoe posobie dlia vuzov. Sevastopol: Publishing SevNTU, 178 p. [In Russian].

Markov, G. T. \& Chaplin, A. F. (1967). Vozbuzhdenie elektromagnitnykh voln. Moscow-Leningrad: Energiia, 376 p. [In Russian].

Markov, G. T., \& Sazonov, D. M. (1975). Antenny: uchebnik dlia studentov radiotekhnicheskikh spetcialnostei VUZov, (2nd ed.). Moscow: Energiia. [In Russian].

Milligan, T. A. (2005). Modern antenna design, (2nd ed.). WileyIEEE Press, $528 \mathrm{p}$.

Patel, Chintan, Masani, Nadeem, \& Parekh, Tushar. (2014). Plasma Antenna. International Journal of Engineering Trends and Techno$\operatorname{logy}$ (IJETT), 15(6), 62-68.

RothenhKusler, B., \& Knoll, W. (1988). Surface-Plasmon Microscopy. Nature, 6165, 615-617.

Sergeichev, K. F., \& Minaev, I. M. (2014). Plazmennye antenny na poverkhnostnykh elektromagnitnykh volnakh. Trudy instituta obshhei fiziki im. A. M. Prokhorova, 7, 53-59. [In Russian].
Shchadylo, Ya. S., Liske, O. M., Hres, M. V., Zharyi, A. A., Tepliakov, I. Yu., \& Yevstafiiev, V. I. (2018a). Dosvid ta perspektyvy vykorystannia plazmovoho rozriadu v systemakh ta zasobakh viiskovoho pryznachennia. Perspektyvy rozvytku ozbroiennia ta viiskovoi tekhniky sukhoputnykh viisk, (pp. 64-72), m. Lviv, 183 p. [In Ukrainian].

Shchadylo, Ya. S., Liske, O. M., Verstivskyi, A. A., Tepliakov, I. Yu., \& Ziniak, B. B. (2018b). Modeliuvannia plazmovoi rebrystoi sterzhnevoi anteny dlia potreb prykhovanoi radiolokatsii. Perspektyvy rozvytku ozbroiennia ta viiskovoi tekhniky sukhoputnykh viisk, (pp. 132-138), m. Lviv, 183 p. [In Ukrainian].

Shpacovitch, Victoria. (2012). Application of Surface Plasmon Resonance (SPR) for the Detection of Single Viruses and Single Biological Nano-objects. Journal of Bacteriology and Parasitology, 3(7), 87-92.

Shriwas, Raviprakash, \& Gulhane, Sayali. (2015). Up gradation of Plasma Antenna by Using Fluorescent Tubes. IPASJ International Journal of Electronics \& Communication (IIJEC), 3(1), 46-51.

Stockman, M. I. (2011). Nanoplasmonics: past, present, and glimpse into future. Optics Express, 19(22), 22029-22106.

Valianskii, S. I. (1999). Mikroskop na poverkhnostnykh plazmonakh. Sorovskii obrazovatelnyi zhurnal, 8, 76-82. [In Russian].

Vecchioni, E., Cerri, G., Russo, P., \& Primiani, V. Mariani. (2016). Experimental and Theoretical Investigation on Plasma Antennas. Università Politecnica delle Marche, via Brecce Bianche, 60131 Ancona, $356 \mathrm{p}$.

Yeatman, Eric M. (1996). Resolution and sensitivity in surface plasmon microscopy and sensing. Biosensors \& Bioelectronics, 11(617), 635-649.

Zheludev, N. I., Prosvirnin, S. L., Papasimakis, N., \& Fedotov, V. A. (2008). Coherent meta-materials and the lasing spaser. Nature Photonics, 2(6), 351-354.

И. Ю. Тепляков, О. М. Лиске, И. В. Гадьо, С. О. Маслаков

\section{ОПЫТ РАЗРАБОТКИ И ИСПОЛЬЗОВАНИЯ СРЕДСТВ ИНФОРМАЦИОННЫХ ТЕХНОЛОГИЙ НА ОСНОВЕ МЕТАЛЛ-ДИЭЛЕКТРИЧЕСКИХ СТРУКТУР И ПЛАЗМЕННОГО РАЗРЯДА}

Приведены результаты анализа принципов построения и примеров применения современных средств информационных технологий на базе металл-диэлектрических структур. Выявлено, что стремительное развитие современных средств информационных технологий обусловлено использованием физических свойств поверхностных плазмонов и поверхностных плазмон-поляритонов. Оценено влияние модуляции поверхностного импеданса металл-диэлектрических структур на форму пространственного распределения поля. Выявлено, что в средствах передачи электромагнитной энергии эффективно используется гофрированная металлическая структура в качестве искусственного диэлектрика для замедления бегущей поверхностной волны. Выяснено, что технология возбуждения поверхностных плазмонов по геометрии Кретчмана по сегодняшний день широко применяемая в средствах инфокоммуникаций. Установлено, что важную роль в развитии современных излучающих средств информационных технологий играет использование высокоионизированного газа в качестве компонента структуры, способной распространять поверхностные плазмон-поляритоны. Выявлен ряд преимуществ средств информационных технологий на базе плазменного разряда, которые обусловлены физическими особенностями плазмы. Исследованы современные информационно-компьютерные технологии модельных исследований электродинамических параметров излучающих средств. На основе проведенного анализа предложено использование ребристо-стержневых структур на базе плазменного разряда в качестве средств передачи электромагнитной энергии.

Ключевые слова: поверхностный плазмон-поляритон; металл-диэлектрическая структура; плазма.

I. Yu. Teplyakov, O. M. Liske, I. V. Gado, S. O. Maslakov

Lviv Polytechnic National University, Lviv, Ukraine

\section{THE EXPERIENCE OF DEVELOPMENT AND USE OF INFORMATION TECHNOLOGY TOOLS BASED ON METAL-DIELECTRIC STRUCTURES AND PLASMA DISCHARGE. OVERVIEW}

The article has presented the analysis results of the construction principles and application examples of the modern information technology tools based on metal-dielectric structures. The authors have revealed that the rapid development of modern information technology tools is due to the using of the physical properties of surface plasmons and surface plasmon polaritons. The modulation impact of the surface impedance of metal-dielectric structures as well as the period and length of metallic radial inhomogeneities on the shape of the spatial field distribution is estimated. This effect can be used in the new tools development, such as antennas, microscopes, biosensors, spasers and interferometers, with the necessary electrodynamic characteristics. Corrugated metal structure is revealed to be used effectively as artificial dielectric for slowing of propagation electromagnetic surface wave in the means of electromagnetic energy transmission. The authors have also found that the excitation technology of surface plasmons and surface plasmon polaritons according to the Kretchman geometry is currently widely used in information technology tools. It has been established that 
the using of highly ionized gas as a component of a structure capable to propagate surface plasmon polaritons plays an important role in the development of modern radiating information technology tools. The number of advantages of information technology tools based on plasma discharge, which are due to the physical characteristics of plasma, are identified. The modern information-computer technologies for electrodynamics modeling of the radiating means parameters have been investigated. The modeling method overviews of the electromagnetic radiators based on the plasma discharge has found that in the research of such means are widely used finite-difference method in the time domain, as well as the finite element method. The analysis which has been performed in this paper enables concluding that corrugated rod structure based on plasma discharge can be used as means of electrodynamics for electromagnetic energy transmission.

Keywords: surface plasmon-polariton; metal-dielectric structure; plasma. 